\title{
O teto de vidro nas organizações públicas: evidências para o Brasil "
}

\author{
Daniela Verzola Vaz.*
}

\begin{abstract}
Resumo
No Brasil, as mulheres ainda são raras nos altos postos de comando das organizações. A percepção desta situação por parte dos dirigentes, no entanto, nem sempre é clara. No serviço público, em particular, a atitude menos discriminatória nas contratações - já que o acesso ao emprego público depende, via de regra, de aprovação prévia em concurso -, e a garantia de igualdade de tratamento a integrantes de uma mesma carreira conduzem à impressão de que o teto de vidro seja menos pronunciado. Este artigo reúne evidências de que, a despeito de seu modo de recrutamento por concurso, as carreiras do setor público brasileiro tampouco escapam ao teto de vidro. A distribuição desigual das mulheres nas distintas instâncias hierárquicas das organizações públicas se faz notar tanto em âmbito administrativo quanto técnico. As práticas discriminatórias sozinhas não explicam o fenômeno, cujas raízes também devem ser buscadas nas intersecções entre vida doméstica e profissional.
\end{abstract}

Palavras-chave: Discriminação; Gênero; Teto de vidro; Setor público.

\begin{abstract}
The glass ceiling in public organizations: the case of Brazil

In Brazil women are still underrepresented in upper-level positions in companies. This situation, however, is frequently not recognized by leaders. In public service, in particular, the adoption of more transparent recruitment practices and the egalitarian treatment to members of the same career may give the misleading impression that the glass ceiling phenomenon is less pronounced. This article gathers evidences that the concerns of the public sector with the adoption of more transparent recruitment practices do not prevent the persistence of hierarchical gender segregation among public employees. Female underrepresentation at the top of public organizations can be observed either in administrative and technical tasks. Discrimination practices alone do not explain the phenomenon, which is also rooted in the intersections between private and professional life.
\end{abstract}

Key words: Discrimination; Gender; Glass ceiling; Public sector.

JEL J710, J450.

\section{Introdução}

Entre as manifestações da segregação de gênero no mercado de trabalho está a segregação hierárquica (ou vertical). Conhecido na literatura como teto de vidro, este fenômeno caracteriza-se pela menor velocidade com que as mulheres ascendem na carreira, o que resulta em sua sub-representação nos cargos de

\footnotetext{
* Trabalho recebido em 14 de julho de 2010 e aprovado em 19 de março de 2012.

** Professora da Escola Paulista de Política, Economia e Negócios da Universidade Federal de São Paulo (Unifesp), São Paulo, SP, Brasil. E-mail: daniela.vaz@unifesp.br.
} 
comando das organizações e, consequentemente, nas altas esferas do poder, do prestígio e das remunerações ${ }^{1}$. É observado mesmo quando as mulheres são dotadas de características produtivas idênticas ou superiores às de seus congêneres do sexo masculino.

No Brasil, de fato, ainda são raras as mulheres em altos cargos corporativos. Entre os funcionários e dirigentes de uma amostra de organizações extraída do grupo das 500 maiores empresas no país, por exemplo, observa-se um "afunilamento hierárquico", ou seja, a incidência de menos mulheres quanto mais elevada é a instância de poder, ainda que o grau de instrução feminino seja superior ao masculino em todos os níveis considerados. Assim, se elas representavam 35\% dos funcionários sem atribuições de comando, em 2007, no quadro executivo (presidente, vice-presidentes e diretores) esse percentual reduzia-se a $11,5 \%$ (Ethos, 2007).

A atitude menos discriminatória do Estado nas contratações - uma vez que o acesso ao emprego público depende, via de regra, de aprovação prévia em concurso de provas e títulos - e a garantia de igualdade de tratamento a integrantes de uma mesma carreira podem conduzir à impressão de que, no serviço público, o teto de vidro seja menos pronunciado. Contribui para essa percepção a forte presença feminina nos escalões inferiores e nos órgãos e áreas de missão social do governo, conforme verificam Bernardes, Moura e Acco (1998).

O objetivo deste trabalho é reunir evidências de que, apesar de adotarem métodos mais objetivos e transparentes de seleção de pessoal, as carreiras do setor público brasileiro tampouco escapam ao teto de vidro. Diversos estudos de caso sugerem, de um lado, que a distribuição desigual das mulheres nas distintas instâncias hierárquicas das organizações públicas se faz notar tanto em âmbito administrativo quanto técnico. De outro, que esse perfil de inserção feminina não é um traço particular da cultura brasileira, sendo igualmente observado em outros países.

O artigo está organizado em quatro seções, além desta. A primeira investiga as principais interpretações encontradas na literatura sobre as causas da segregação hierárquica de gênero. Na seção seguinte realiza-se a revisão de trabalhos que se reportaram ao fenômeno no setor público brasileiro, buscando-se reunir evidências adicionais dele, a fim de enriquecer a discussão. Enfrentou-se, entretanto, dificuldade em encontrar dados consolidados desagregados por sexo a

(1) Entende-se a segregação hierárquica como algo distinto da segregação ocupacional, que se refere à tendência à alocação de homens e mulheres em segmentos ocupacionais distintos do mercado de trabalho. Na prática, no entanto, os efeitos desses fenômenos se confundem, pois as próprias ocupações podem ser hierarquizadas conforme o prestígio e a remuneração que lhes são atribuídos, observando-se a preponderância feminina nas atividades menos prestigiadas e mais malremuneradas. Optamos, entretanto, pelo estudo desses eventos em separado, sendo a segregação hierárquica propriamente dita objeto deste artigo. 
respeito do nível hierárquico assumido pelos indivíduos nas organizações estatais ${ }^{2}$. s casos que se logrou analisar foram o dos servidores da administração pública federal que ocupam cargos em comissão do grupo direção e assessoramento superiores (DAS) e o dos docentes da Universidade Estadual de Campinas. Na terceira seção busca-se contribuir para o entendimento do quadro verificado nessas duas organizações, discutindo suas causas. Para encerrar a análise, na última seção são reunidos os principais resultados alcançados e apresentadas as conclusões.

\section{Causas da segregação hierárquica de gênero no mercado de trabalho}

É possível identificar dois modelos complementares de interpretação do fenômeno do teto de vidro: o primeiro remete às práticas discriminatórias, manifestas ou veladas, que visam excluir as mulheres das posições de poder, enquanto o segundo enfatiza a menor predisposição feminina a assumir cargos de comando (Marry, 2008).

A primeira dessas abordagens, de natureza sócio-histórica, ressalta os mecanismos de exclusão feminina, como as barreiras historicamente enfrentadas pelas mulheres para ingressarem no ensino superior, em particular em instituições de prestígio, o que durante muito tempo as impediu de se qualificarem para disputar as posições mais prestigiadas no mercado de trabalho. Dentro dessa linha de interpretação podem-se citar trabalhos como os de Schweitzer (2008), Beltrão e Alves (2004) e Beltrão e Teixeira (2005).

Schweitzer (2008), por meio de uma síntese da evolução dos sistemas de ensino e de produção nos principais países europeus ao longo dos séculos XIX e $\mathrm{XX}$, mostra que a incorporação em massa das mulheres ao mercado de trabalho assalariado esteve relacionada muito mais aos momentos de inflexão econômica e social vivenciados em conjunto por esses países, que às suas especificidades culturais e políticas. Em particular, a autora mostra que as transformações econômicas e sociais ocasionadas pelas três grandes revoluções industriais encontraram, sucessivamente, eco em reformas do sistema de ensino que resultaram no gradual acesso das mulheres às instituições de formação técnica e superior, dando-lhes condições de competir pelas profissões mais prestigiadas.

Beltrão e Alves (2004) apontam as dificuldades femininas no acesso à escola e que resultaram em um acentuado hiato de gênero na educação brasileira, revertido apenas a partir de meados do século XX. O ingresso em grande escala das mulheres na educação superior, por exemplo, tornou-se uma realidade apenas com a Lei de Diretrizes e Bases da Educação, de 1961, que equiparou a escola normal

(2) Cabe observar que as pesquisas domiciliares realizadas pelo IBGE e os registros administrativos geridos pelo Ministério do Trabalho e Emprego captam informações a respeito da ocupação desempenhada pelos indivíduos no mercado de trabalho, mas não da função por eles assumida. 
aos demais cursos de segundo grau, permitindo aos indivíduos que faziam o magistério - a grande maioria das mulheres - disputarem o vestibular. A partir desse momento, a presença feminina nas carreiras superiores tornou-se crescente $^{3}$, permitindo a gradual eliminação do hiato educacional entre os gêneros, medido em termos do número médio de anos de estudo formal concluídos com sucesso por homens e mulheres ${ }^{4}$.

Beltrão e Teixeira (2005) analisam a razão de sexo nas carreiras levantadas nos censos realizados entre 1960 e 2000, verificando que, a cada edição do recenseamento, é maior a proporção de mulheres em quase todas elas. Também constatam que, paralelamente ao aumento da oferta de cursos, cresce o número de carreiras que apresentam predominância feminina: eram 32\% em 1960, 39\% em 1970, 43\% em 1980, 44\% em 1991 e 46\% em 2000. O resultado mais interessante encontrado pelos autores, no entanto, é que, na comparação entre as representatividades de sexo e cor nas diferentes carreiras, constata-se que as carreiras mais "femininas" têm maior participação de pretos e pardos. Esse resultado corrobora a hipótese de que as profissões mais "femininas" têm um valor de mercado e social mais baixo, já que estudos anteriores mostram que os grupos de cor menos privilegiados inserem-se preferencialmente em carreiras de menor status e prestígio social, nas quais é mais fácil o ingresso nos exames vestibulares.

À medida que as barreiras sócio-históricas enfrentadas pelas mulheres para se qualificarem e ingressarem no mercado de trabalho são superadas, ganham destaque os trabalhos que, sem negligenciar essa vertente, buscam nas relações entre vida profissional e pessoal e na divisão sexual do trabalho as causas da persistência da preeminência masculina nas posições elevadas. Segundo essa linha de interpretação, as mulheres se autoexcluem dos cargos de liderança e mesmo de carreiras de maior prestígio e remuneração em razão da interiorização de normas de socialização que pregam a necessidade de serem atenciosas e prestativas qualidades conflitantes com a ambição profissional. Adicionalmente, porque desejam evitar os obstáculos e conflitos que anteveem para conciliar suas vidas profissionais e familiares, e que normalmente são potencializados nas posições de comando e nas carreiras de maior prestígio.

A maior parte dos trabalhos combina distintas abordagens para investigar as causas da segregação vertical nas organizações. Grosso modo, os trabalhos realizam comparações internacionais e/ou analisam a construção das relações sociais de gênero em carreiras específicas.

(3) Na Unicamp, por exemplo, o percentual de mulheres entre os ingressantes na universidade passou de 24,7\% em 1970 para 43,5\% em 2005 (Brisolla, Vasconcellos e Pimentel, 2007).

(4) Esse hiato foi revertido entre os censos de 1980 e 1991, tornando-se, a partir de então, crescentemente favorável às mulheres. 
Lombardi (2008), por exemplo, procura identificar os fatores que dificultam a ascensão das engenheiras a postos de comando, com base em entrevistas com indivíduos de ambos os sexos que, em algum momento de suas carreiras, ascenderam a esses cargos. A importância desse trabalho é que ele ressalta dificuldades que, ainda que potencializadas no caso das engenheiras, atingem a maioria das mulheres que desempenham profissões historicamente ocupadas por maioria masculina e nas quais a presença feminina em cargos de comando é reduzida. Entre os fatores identificados pela autora estão:

a) A vigência de estratégias empresariais que colocam obstáculos à ascensão das mulheres. Frequentemente a empresa não privilegia as especialidades e áreas de trabalho assumidas pelas mulheres, embora isso pareça não acontecer quando as mesmas áreas são ocupadas por homens.

b) A existência de espaços informais de trocas entre colegas, dos quais as mulheres são alijadas, e nos quais, ao lado de assuntos alheios ao trabalho, como esportes, são discutidas questões profissionais, realizam-se trocas de favores e indicações de colegas para preenchimento de cargos.

c) A exigência de maior disponibilidade para estender o expediente até mais tarde e realizar viagens nos cargos de alto escalão, o que tornaria mais difícil para as mulheres a conciliação entre a vida profissional e a familiar, já que sobre elas recai a maior parte das responsabilidades no cuidado dos filhos.

d) A resistência feminina a assumir postos de comando, seja por antever as dificuldades que serão enfrentadas para conciliar as exigências profissionais e as obrigações familiares, seja por preferir se preservar a enfrentar a acirrada competição por esses cargos.

e) A dificuldade que grupos de engenheiros enfrentam em aceitar serem chefiados por mulheres, o que muitas vezes pode conduzir a situações de conflito aberto. Esse preconceito exige que, ao longo da ascensão profissional, as engenheiras tenham continuamente que provar sua competência perante o grupo, algo que não é requerido de colegas homens em situação semelhante.

f) Em ambientes tipicamente masculinos, a avaliação de desempenho dos funcionários se baseia em valores e critérios masculinos. Assim, atributos mais presentes nas mulheres, como a habilidade nos relacionamentos e a capacidade de conciliação de conflitos, são menos valorizados. Para alcançar postos de comando em organizações, as mulheres frequentemente são obrigadas a abdicar de um estilo próprio e mais "feminino" de chefia, em favor de uma atuação profissional mais racional e impessoal, que é mais valorizada.

Ainda tratando das engenheiras, Georges (2008) compara as relações entre vida doméstica e profissional no setor de telecomunicações no Brasil e na França. 
Por meio de entrevistas, a autora verifica que mesmo dispondo de maiores mecanismos de apoio à carreira que suas congêneres francesas - em razão da ampla utilização do trabalho doméstico assalariado no Brasil pelas classes média e alta -, as engenheiras brasileiras continuam enfrentando obstáculos à mobilidade hierárquica em razão da interiorização dos papéis de esposa e de mãe, da autolimitação nas escolhas profissionais, da prioridade atribuída à carreira do cônjuge e dos mecanismos de exclusão que enfrentam nas empresas. Ou seja, mesmo com a facilidade de acesso à mão de obra para realizar as tarefas domésticas e cuidar das crianças, a divisão social e sexual tradicional do trabalho resiste no Brasil.

Hirata e Kergoat (2008) mostram que, de fato, o modelo de articulação entre vida profissional e familiar predominante no Brasil, pautado na delegação das tarefas domésticas e de cuidado dos filhos a outras mulheres, mascara, mas não resolve as tensões entre os sexos geradas pela repartição desigual das atribuições domésticas e familiares. As mulheres pobres, ademais, seguem acumulando tais atribuições com o trabalho remunerado, dependendo dos filhos mais velhos e de uma ampla rede informal de solidariedade que inclui parentes, amigos e vizinhos para conciliar suas atividades ${ }^{5}$.

\section{0 teto de vidro no setor público brasileiro}

Diversas evidências sugerem que o setor público tampouco escapa ao fenômeno do teto de vidro, sendo ainda raras as mulheres em altos postos de comando na administração pública ou nas organizações de ensino e pesquisa.

\subsection{O caso da administração pública federal}

$\mathrm{Na}$ administração pública federal, é possível constatar o teto de vidro ao se analisar a participação feminina nos cargos em comissão do grupo direção e assessoramento superiores (doravante DAS). Esses cargos destinam-se às atribuições de direção, chefia e assessoramento no âmbito da administração pública federal direta, autárquica e fundacional. São preenchidos por nomeação, têm

(5) A autora também compara a situação das mulheres brasileiras com a vivenciada pelas francesas e japonesas. Na França, o modelo de delegação coexiste com o intitulado "modelo de conciliação", caracterizado pelo desempenho feminino tanto de atividades profissionais como da maior parte dos encargos familiares. $\mathrm{O}$ primeiro é viabilizado pela presença, naquele país, de imigrantes em busca de um emprego no setor de serviços; o segundo, pela existência de políticas públicas destinadas a facilitar o acesso de mulheres desempregadas com filhos ao mercado de trabalho. No Japão, em contraste, o modelo de delegação é praticamente inexistente, em razão da dominância de normas sociais segundo as quais compete às mães de família cuidar dos filhos e da casa. Por outro lado, a ausência de políticas públicas de apoio ao trabalho feminino em tempo integral e a menor participação do cônjuge na realização das tarefas domésticas tornam a possibilidade de conciliar vidas familiar e profissional muito mais difícil, exigindo, via de regra, a abdicação da atividade profissional em tempo integral por ocasião da maternidade. 
caráter provisório e podem ou não ser ocupados por servidores de carreira do Estado. Existem seis níveis de cargos em comissão DAS, a depender do poder decisório associado ao posto. O cargo DAS 6, de maior colocação hierárquica, é reservado a secretários de órgãos finalísticos, dirigentes de autarquias e fundações e subsecretários de órgãos da Presidência da República.

Observa-se que, quanto mais alto o DAS, isto é, quanto maior o nível decisório associado ao posto de trabalho, menor a participação feminina. Assim, em novembro de 2009, as mulheres ocupavam 45,3\% das funções do tipo DAS 1, mas apenas 23,7\% dos cargos DAS 5 e 20,9\% das funções DAS 6. Ainda que esses percentuais tenham apresentado, na última década, tendência de elevação, esse movimento é lento e errático, principalmente quando se trata dos maiores níveis hierárquicos (Tabela 1).

A desigual distribuição de homens e mulheres nos cargos do tipo DAS responde por um diferencial salarial importante entre os gêneros nessas funções. A remuneração média global (referente ao cargo e à função) dos servidores DAS 1 ( $\mathrm{R} \$$ 9.988,71, em fevereiro de 2010), por exemplo, representa $61,1 \%$ daquela auferida, em média, pelos ocupantes de cargos do tipo DAS 4, e 50,8\% da recebida pelos servidores DAS 6.

Tabela 1

Participação feminina (em \%) no total de ocupantes dos cargos em comissão do grupo direção e assessoramento superiores (DAS), segundo o nível de função. Brasil, 1997 a 2009

\begin{tabular}{lccccccc}
\hline & DAS 1 & DAS 2 & DAS 3 & DAS 4 & DAS 5 & DAS 6 & Total \\
\hline Nov./97 & 45,3 & 39,6 & 37,5 & 29,3 & 16,7 & 14,4 & 39,6 \\
Nov./98 & 46,2 & 40,4 & 38,8 & 30,7 & 16,5 & 12,3 & 40,3 \\
Nov./99 & 47,8 & 40,8 & 39,4 & 31,7 & 18,7 & 13,2 & 40,9 \\
Nov./00 & 49,0 & 40,9 & 39,8 & 33,1 & 18,9 & 15,1 & 41,9 \\
Nov./01 & 49,3 & 42,1 & 40,9 & 33,3 & 21,0 & 14,6 & 42,6 \\
Nov./02 & 50,2 & 43,3 & 40,6 & 35,8 & 23,1 & 18,3 & 43,5 \\
Nov./03 & 46,9 & 45,7 & 42,1 & 36,5 & 21,7 & 19,3 & 43,0 \\
Nov./04 & 47,8 & 46,1 & 44,4 & 36,1 & 22,6 & 16,6 & 43,7 \\
Nov./05 & 47,4 & 46,7 & 45,7 & 36,7 & 22,6 & 14,5 & 44,0 \\
Nov./06 & 46,8 & 46,1 & 46,8 & 38,3 & 23,9 & 18,0 & 44,0 \\
Nov./07 & 45,5 & 46,0 & 46,0 & 38,2 & 23,1 & 20,0 & 43,3 \\
Nov./08 & 45,5 & 45,0 & 45,1 & 37,1 & 22,9 & 20,0 & 42,7 \\
Nov./09 & 45,3 & 45,4 & 45,5 & 37,4 & 23,7 & 20,9 & 42,9 \\
\hline
\end{tabular}

Fonte: Boletim Estatístico de Pessoal (vários números). Secretaria de Recursos Humanos/Ministério do Planejamento, Orçamento e Gestão. Disponível em: <http://www.servidor.gov.br/publicacao/boletim_estatistico/bol_estatistico.htm>. Acesso em: 12 jul. 2010. Elaboração própria. 
Bernardes; Moura e Acco (1998) e Fontenele-Mourão (2006) observam que esse perfil de participação desigual das mulheres nas distintas instâncias hierárquicas da administração pública não é um traço particular da cultura brasileira, sendo igualmente observado em países como Grã-Bretanha, Estados Unidos, Austrália e Canadá.

Na França, o teto de vidro no serviço público tampouco se mostra em vias de ser superado. Apesar de a legislação francesa - tal como a brasileira determinar a realização de concursos para investidura na maioria dos cargos públicos e garantir igualdade de tratamento graças ao sistema de carreira, as situações de segregação hierárquica não foram eliminadas. Assim, naquele país, embora as mulheres representem 59,1\% dos 5,2 milhões de servidores públicos, elas ocupam apenas $16 \%$ dos cargos de direção (Direction Générale de l'Administration et de la Fonction Publique - DGAFP, 2008 - dados referentes a 31/12/2006).

Cabe observar que a baixa representatividade feminina em cargos de comando é verificada nos três segmentos em que o Estado francês está subdividido. No governo central (État) ${ }^{6}$, as mulheres representam 50,8\% dos efetivos, mas apenas $15,3 \%$ dos dirigentes (exclusive militares). Nos serviços públicos atinentes às subdivisões administrativas do território (fonction publique territoriale) ${ }^{7}$, elas veem sua representação - que é de $61 \%$ - diminuir para $16,1 \%$ na hierarquia superior. Finalmente, na saúde pública (fonction publique hospitalière) ${ }^{8}$, embora perfaçam mais de $3 / 4$ dos servidores, são apenas $16,4 \%$ dos dirigentes.

\subsection{A condição feminina nas organizações públicas de ensino e pesquisa}

\subsubsection{Uma revisão de estudos recentes}

A exemplo do que ocorre na direção do serviço público federal, no meio científico nacional as mulheres ainda são minoria nos postos de maior hierarquia.

De acordo com Leta et al. (2006), por exemplo, embora representassem $55,10 \%$ dos alunos de graduação, 51,41\% dos estudantes de mestrado e 48,93\% dos doutorandos agraciados com bolsas de estudo do Conselho Nacional de Desenvolvimento Científico e Tecnológico (CNPq) em 2004, as mulheres

(6) Esta função pública se subdivide em administrations centrales de l’État e services déconcentrés. O primeiro caso remete às atribuições centrais dos ministérios, situados geralmente em Paris, tendo como objetivo a concepção e coordenação das ações do Estado em nível nacional. O segundo caso concerne às ações do Estado em nível regional e departamental.

(7) Esta função foi criada em 1984 com o objetivo de transferir às coletividades territoriais (regiões, departamentos e comunas) a responsabilidade pelos serviços de interesse local. Ela compreende, portanto, o conjunto de empregos das subdivisões administrativas do território francês e de seus estabelecimentos públicos.

(8) Esta função agrupa o conjunto de funcionários (exclusive médicos, biólogos, farmacêuticos e dentistas) dos seguintes estabelecimentos públicos ou de caráter público franceses: hospitais, asilos, orfanatos, estabelecimentos para menores infratores, estabelecimentos para deficientes, abrigos e centros de readaptação social. 
representavam apenas $33,28 \%$ dos pesquisadores premiados com a bolsa de produtividade em pesquisa dessa agência ${ }^{9}$. Entre os pesquisadores nomeados para comitês de assessoramento, eram 22,8\% em 2006. Entre os docentes nomeados para cargos de chefia na Universidade Federal do Rio de Janeiro elas figuravam como $24 \%$ em 2004.

Na Academia Brasileira de Ciências, uma das mais antigas e prestigiadas associações de cientistas do país, as mulheres perfaziam, em 2002, apenas 7,8\% dos membros titulares (Melo; Casemiro, 2003) ${ }^{10}$. Analisando a participação feminina segundo área de especialização, encontrava-se um percentual de $36,4 \%$ de mulheres no corpo de titulares das Ciências Humanas. Tal valor, porém, pouco contribuía para elevar a participação média feminina, pois tal área, criada em 1999, tinha importância diminuta, em termos de número de filiados, no conjunto da Academia.

Observando, por outro lado, a distribuição dos acadêmicos segundo categoria, verificava-se que $60 \%$ dos homens eram membros titulares, percentual que se reduzia a $46,4 \%$ no caso das mulheres. Considerando que a indicação e eleição de novos titulares é realizada anualmente pelos membros preexistentes, tendo como critérios o mérito científico do candidato e a contribuição prestada ao desenvolvimento da ciência no país, conclui-se que "o meio científico ainda reconhece de forma tímida o papel feminino no sistema científico e tecnológico" nacional. Haja vista o fato de essa associação, fundada em 1916, nunca ter sido presidida por uma mulher e, ao longo do século XX, ter admitido em seus quadros apenas 66 mulheres, face a 1009 homens ${ }^{11}$.

Apesar da longa trajetória que consolidou a ciência moderna na França, perfil semelhante de segregação hierárquica é encontrado naquele país. Embora recebam 39,6\% das bolsas concedidas pelo Ministério da Pesquisa francês, as mulheres são minoria entre os professores titulares de universidades e institutos de pesquisa $(17,3 \%)$, entre os membros dos comitês científicos do Ministério da Pesquisa $(26,1 \%)$ e na Academia de Ciências $(5,1 \%)$ (Leta et al., 2006, dados referentes a 2004).

(9) Melo e Lastres (s.d.) traçam um quadro detalhado da inserção feminina no sistema brasileiro de pesquisa científica e tecnológica entre 1990 e 1999, por meio da análise dos dados do Diretório de Grupos de Pesquisa do CNPq. As autoras constatam que, nessa década, as mulheres aumentaram sua participação nas bolsas de formação concedidas pelo CNPq (iniciação científica, mestrado e doutorado), porém mantiveram quase idêntica sua participação naquelas que refletem a maturidade dos pesquisadores (produtividade em pesquisa e pósdoutorado). Observam ainda que, em se tratando das bolsas de produtividade em pesquisa e pós-doutorado, a taxa de participação feminina decresce à medida que aumenta a classificação atribuída ao pesquisador.

(10) Cabe assinalar que este percentual, em 2006, era de 11\%, segundo Leta et al. (2006).

(11) A exclusão feminina mostra-se ainda mais acentuada na Academia Nacional de Medicina, que, desde sua fundação, em 1829, até o ano de 2002, admitiu apenas nove mulheres em seus quadros, embora conte permanentemente com cem vagas para membros titulares, além de membros eméritos, honorários e sócios correspondentes (Melo; Casemiro, 2003). 
Em duas das mais renomadas instituições de pesquisa francesas - o Centre National de la Recherche Scientifique (CNRS) e o Institut de Recherche Agronomique (INRA) -, elas são promovidas com menos frequência aos cargos de direção (Marry, 2008) ${ }^{12}$. As causas dessas diferenças, segundo a autora, subjazem na vigência de critérios aparentemente neutros para promoção nesses dois institutos, que acabam por punir as mulheres. Como exemplos, menciona-se a preferência - ainda que subjetiva - dos avaliadores por candidatos mais jovens e que trilharam uma ascensão profissional mais rápida - algo mais frequente entre os homens, cuja carreira não é interrompida pela maternidade - e por pesquisadores que adotem uma visão de ciência segundo a qual esta exige um envolvimento total, uma verdadeira devoção. Essa visão de profissionalismo supõe a disponibilidade irrestrita, tanto temporária como em termos de mobilidade geográfica, ao trabalho, algo mais caro às mulheres, que sentem maior dificuldade em conciliar os compromissos profissionais e familiares - já que estes recaem em maior medida sobre elas que sobre seus cônjuges - e em abdicar de seu tempo em família para se dedicar ao cargo.

\subsubsection{O caso da Universidade Estadual de Campinas}

Um retrato da evolução recente da representatividade feminina nos níveis superiores da hierarquia acadêmica pode ser encontrado na Universidade Estadual de Campinas (Unicamp). Nas Tabelas 2 e 3, a seguir, observa-se a distribuição dos docentes ativos dos sexos masculino e feminino nos diferentes níveis da carreira docente do magistério superior (MS) ${ }^{13}$ nessa Universidade, entre 1994 e 2009.

Cabe observar, preliminarmente, que no final do ano 2000 a Unicamp suprimiu o nível de professor livre-docente (MS-4), determinando a progressão direta de doutor (MS-3) para associado (MS-5) após a obtenção do título de livredocência, mediante aprovação em concurso de provas e títulos. Foram ainda extintos os níveis MS-1 e MS-2, o que implicou a impossibilidade de contratação de novos profissionais sem o título de doutor. De fato, a política dessa Universidade tem sido, desde muito antes de 2000, a de cobrar de seus docentes o título de doutor e evitar a contratação de novos profissionais sem essa titulação. Assim, observa-se, no período considerado, a diminuição sistemática no percentual

(12) No INRA, por exemplo, em se tratando da carreira de biólogo e considerando dossiês e percursos iguais, a probabilidade de ascender ao grau de diretor de pesquisa é $15 \%$ menor para as mulheres que para os homens.

(13) Os docentes desta carreira podem ser contratados sob três diferentes regimes de trabalho: o regime de turno parcial (RTP), que corresponde a 12 horas semanais de trabalho, o regime de turno completo (RTC), associado a 24 horas semanais de trabalho, e o regime de dedicação integral à docência e à pesquisa (RDIDP), que exige uma carga semanal de trabalho de 40 horas. Esses três regimes, em 2009, respondiam por, respectivamente, 2\%, $9 \%$ e $88 \%$ dos docentes ativos na carreira MS na Unicamp, não tendo sido observadas modificações importantes nessa distribuição no período 1994-2009. 
de instrutores e assistentes, os quais, em seu conjunto, passaram de 26,1\% dos docentes ativos em 1994 para 2,4\% em 2009.

Ao comparar as Tabelas 2 e 3 verifica-se que houve até 1999 - no caso dos homens - e 2000 - em se tratando das mulheres - um aumento persistente no percentual de doutores. Esse comportamento reflete, conforme mencionado, a política da universidade de estabelecer essa titulação como pré-requisito para o exercício da docência. Após 1999, a proporção de doutores entre os docentes do sexo masculino apresentou tendência à estagnação, oscilando em torno de $40 \%$. Entre as mulheres, o movimento, iniciado em 2000, foi de declínio sistemático, indicando o avanço delas para níveis hierárquicos superiores. De fato, se em 1994 apenas 3,1\% das professoras haviam atingido o cargo de titular, em 2009 esse percentual havia crescido mais de cinco vezes.

Apesar dos avanços femininos na carreira no período considerado, ao final da série mais da metade das docentes ainda se encontravam no nível MS-3, ao passo que, entre os homens, observava-se uma distribuição mais equilibrada entre os três níveis hierárquicos superiores. Esse resultado indica, por um lado, a maior facilidade de progressão profissional masculina. Por outro, aponta para a tendência feminina a superar essa diferença, tendo em vista o aumento sistemático na proporção de titulares entre as docentes do sexo feminino a partir de 1996.

Tabela 2

Distribuição (em \%) dos docentes ativos na carreira de magistério de nível superior do sexo masculino. Unicamp, 1994 a 2009

\begin{tabular}{lcccccc|c}
\hline Ano & $\begin{array}{c}\text { Instrutor } \\
(\text { MS-1 })\end{array}$ & $\begin{array}{c}\text { Assistente } \\
(\text { MS-2) }\end{array}$ & $\begin{array}{c}\text { Doutor } \\
\text { (MS-3) }\end{array}$ & $\begin{array}{c}\text { Livre- } \\
\text { Docente } \\
(\text { MS-4) }\end{array}$ & $\begin{array}{c}\text { Associado } \\
(\text { MS-5) }\end{array}$ & $\begin{array}{c}\text { Titular } \\
\text { (MS-6) }\end{array}$ & Total \\
\hline 1994 & 1,7 & 21,7 & 35,2 & 17,5 & 10,0 & 13,9 & 100,0 \\
1995 & 1,6 & 18,9 & 37,3 & 17,5 & 11,1 & 13,5 & 100,0 \\
1996 & 1,1 & 16,6 & 39,9 & 17,7 & 11,1 & 13,7 & 100,0 \\
1997 & 0,9 & 12,8 & 42,8 & 18,5 & 10,6 & 14,4 & 100,0 \\
1998 & 0,6 & 10,8 & 44,6 & 19,2 & 10,8 & 13,9 & 100,0 \\
1999 & 0,6 & 8,7 & 44,7 & 20,8 & 10,0 & 15,1 & 100,0 \\
2000 & 0,6 & 7,4 & 43,1 & 22,5 & 10,8 & 15,6 & 100,0 \\
2001 & 0,4 & 6,6 & 41,0 & - & 35,2 & 16,8 & 100,0 \\
2002 & 0,4 & 5,9 & 39,3 & - & 36,8 & 17,6 & 100,0 \\
2003 & 0,4 & 6,0 & 38,1 & - & 37,6 & 17,9 & 100,0 \\
2004 & 0,3 & 5,7 & 39,0 & - & 35,9 & 19,0 & 100,0 \\
2005 & 0,3 & 4,9 & 39,1 & - & 35,3 & 20,4 & 100,0 \\
2006 & 0,3 & 4,6 & 39,6 & - & 33,8 & 21,7 & 100,0 \\
2007 & 0,3 & 3,6 & 40,7 & - & 32,6 & 22,8 & 100,0 \\
2008 & 0,3 & 3,2 & 39,6 & - & 33,9 & 23,0 & 100,0 \\
2009 & 0,3 & 3,1 & 38,9 & - & 33,9 & 23,8 & 100,0 \\
\hline
\end{tabular}

Fonte: Anuários Estatísticos da Unicamp (1995-2010). Disponíveis em: http://www.aeplan. unicamp.br. Acesso em: 12 jul. 2010. Elaboração própria. 
Tabela 3

Distribuição (em \%) dos docentes ativos na carreira de magistério de nível superior do sexo feminino. Unicamp, 1994 a 2009

\begin{tabular}{lcccccc|c}
\hline Ano & $\begin{array}{c}\text { Instrutor } \\
\text { (MS-1) }\end{array}$ & $\begin{array}{c}\text { Assistente } \\
(\text { MS-2) }\end{array}$ & $\begin{array}{c}\text { Doutor } \\
(\text { MS-3) }\end{array}$ & $\begin{array}{c}\text { Livre- } \\
\text { Docente } \\
(\text { MS-4) }\end{array}$ & $\begin{array}{c}\text { Associado } \\
(\text { MS-5) }\end{array}$ & $\begin{array}{c}\text { Titular } \\
(\text { MS-6) }\end{array}$ & Total \\
\hline 1994 & 1,8 & 29,5 & 50,1 & 11,5 & 3,9 & 3,1 & 100,0 \\
1995 & 1,2 & 26,7 & 52,7 & 12,0 & 4,7 & 2,7 & 100,0 \\
1996 & 0,9 & 22,0 & 57,2 & 12,3 & 5,2 & 2,4 & 100,0 \\
1997 & 0,6 & 17,7 & 59,6 & 14,1 & 5,5 & 2,5 & 100,0 \\
1998 & 0,6 & 13,5 & 62,4 & 14,6 & 5,9 & 3,0 & 100,0 \\
1999 & 0,3 & 8,4 & 63,6 & 17,6 & 6,3 & 3,9 & 100,0 \\
2000 & 0,3 & 5,4 & 65,1 & 18,6 & 6,0 & 4,6 & 100,0 \\
2001 & 0,2 & 4,2 & 62,8 & - & 26,5 & 6,3 & 100,0 \\
2002 & 0,0 & 3,5 & 59,8 & - & 29,3 & 7,5 & 100,0 \\
2003 & 0,0 & 2,8 & 57,1 & - & 31,1 & 9,0 & 100,0 \\
2004 & 0,0 & 2,2 & 56,8 & - & 31,2 & 9,7 & 100,0 \\
2005 & 0,0 & 2,3 & 56,8 & - & 30,2 & 10,7 & 100,0 \\
2006 & 0,0 & 2,2 & 56,0 & - & 29,1 & 12,7 & 100,0 \\
2007 & 0,0 & 1,5 & 55,4 & - & 28,9 & 14,2 & 100,0 \\
2008 & 0,0 & 0,7 & 52,9 & - & 31,7 & 14,7 & 100,0 \\
2009 & 0,0 & 0,7 & 54,1 & - & 29,5 & 15,8 & 100,0 \\
\hline
\end{tabular}

Fonte: Anuários Estatísticos da Unicamp (1995-2010). Disponíveis em: <http://www.aeplan. unicamp.br>. Acesso em: 12 jul. 2010. Elaboração própria.

No Gráfico 1 verifica-se que, embora não tenham conseguido ampliar sua fatia no total de vagas de docentes na Unicamp ${ }^{14}$, as mulheres lograram aumentar sua participação nos níveis superiores dessa carreira no período analisado. Entre os professores livre-docentes (categoria existente até 2000) e associados, elas passaram de 22,3\%, em 1994, para pouco menos de 1/3 do total em 2009. Entre os titulares, o avanço feminino foi mais acelerado, observando-se o crescimento de sua participação de $10,1 \%$ para mais de $1 / 4$ no mesmo período. Resta, é verdade, um longo caminho a trilhar, a fim de se alcançar uma participação mais equitativa entre os gêneros nos distintos degraus da hierarquia da carreira docente nessa universidade, sendo importante, para a consecução dessa meta, que as tendências observadas no Gráfico 1 não sofram desaceleração nos próximos anos.

(14) As mulheres representavam, em 2008, 34,2\% do total de docentes ativos da Unicamp, percentual muito próximo daquele verificado na Universidade de São Paulo em 2007 (35,9\%). 
Gráfico 1

Evolução da proporção de mulheres (em \%) entre os docentes ativos na carreira de magistério de nível superior. Unicamp, 1994 a 2009

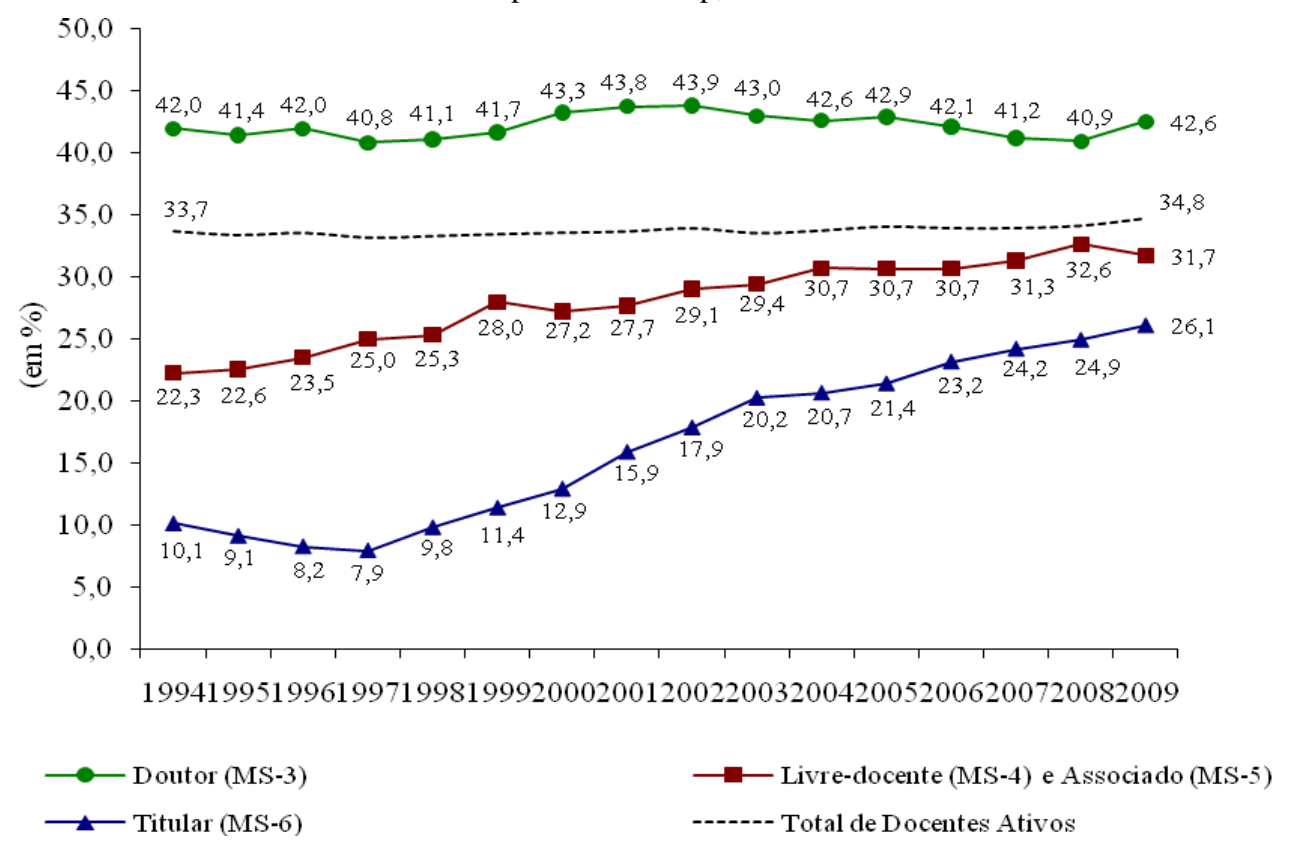

Fonte: Anuários Estatísticos da Unicamp (1995-2010). Disponíveis em: <http://www.aeplan. unicamp.br>. Acesso em: 12 jul. 2010. Elaboração própria.

Ainda que encorajadores, esses dados não podem mascarar o fato de se observarem discrepâncias muito grandes entre os 21 institutos e faculdades que integram a Unicamp. Velho e León (1998), por exemplo, ao analisarem a distribuição dos docentes de cada sexo nos institutos de Física, Química, Biologia e Ciências Humanas e Sociais em 1996, observaram que a proporção das docentes mulheres que se encontravam no nível MS-5 oscilava entre $21,4 \%$, no Instituto de Física, e 1,6\%, no Instituto de Biologia. O quadro mais desfavorável para as mulheres em termos de segregação hierárquica, porém, foi encontrado justamente no instituto responsável pelas áreas de conhecimento tradicionalmente identificadas como femininas, o de Filosofia e Ciências Humanas.

Deve-se observar ainda que, apesar da maior velocidade com que as mulheres têm progredido na carreira docente na Unicamp, isso não implicou a eliminação da segregação de gênero nos cargos administrativos dessa universidade. Nas chefias de departamento das unidades acadêmicas elas atingiam, em 2006, quase um terço do total (40 de 125). Nos altos postos diretivos, no entanto, que incluem as diretorias de unidades, as pró-reitorias e a reitoria, a relação passava a apenas um sétimo (4 de 29) (Brisolla; Vasconcellos; Pimentel, 2007). 


\subsubsection{Análise das informações do Censo da Educação Superior}

Nesta subseção, são analisados os dados do Censo da Educação Superior, realizado anualmente pelo Instituto Nacional de Estudos e Pesquisas Educacionais Anísio Teixeira (INEP), autarquia vinculada ao Ministério da Educação.

Essa pesquisa reúne informações sobre as instituições de educação superior (doravante IES) do país, como o número de vagas e de cursos oferecidos - sejam eles presenciais ou à distância -, a quantidade de candidatos inscritos nos processos de seleção, de ingressantes, de matriculados e de concluintes. Contabiliza, ainda, os docentes em exercício e afastados, oferecendo informações sobre seu grau de formação e regime de trabalho.

Esses dados podem ser desagregados geograficamente e segundo as diferentes formas de organização acadêmica e categoria administrativa das instituições. Devido ao escopo deste trabalho, restringiremos a análise às IES classificadas, no tocante à categoria administrativa, como públicas.

Em 2007 havia 108.828 funções docentes sendo exercidas em instituições públicas de educação superior no Brasil. Desse total, 88,0\% encontravam-se vinculadas às Universidades, 6,1\% aos Centros Federais de Educação Tecnológica e às Faculdades de Tecnologia e 4,9\% às Faculdades, Escolas e Institutos. Apenas $1 \%$ dos vínculos era exercido em Centros Universitários ou Faculdades Integradas, formas de organização acadêmica mais típicas do setor privado.

Na Tabela 4 observamos a evolução da proporção de mulheres nas funções docentes ${ }^{15}$ em exercício, segundo a categoria administrativa da instituição e o tipo de organização acadêmica, entre 2002 e 2007. As informações coletadas referem-se ao $1^{\mathrm{o}}$ semestre de cada ano.

A proporção de mulheres no total de funções em exercício aumentou de forma lenta, ainda que sistemática, no período considerado, tendo passado de 41,4\% em 2002 para 43,7\% em 2007.

Observa-se ainda que, a partir de 2005, a proporção feminina no total de funções vinculadas às Faculdades, Escolas e Institutos tornou-se ligeiramente superior à encontrada nas Universidades. Em contrapartida, as mulheres seguiram sub-representadas nos Centros Federais de Educação Tecnológica e nas Faculdades de Tecnologia, ainda que tenham elevado sua representação nessas organizações de $26,5 \%$ em 2002 para 32,3\% em 2007.

(15) Cabe atentar para o fato de o número de funções docentes não corresponder, necessariamente, ao número de docentes, pois os profissionais que trabalham em mais de um estabelecimento são declarados por todas as IES nas quais exercem alguma função. 
Tabela 4

Evolução da proporção de mulheres nas funções docentes em exercício, segundo categoria administrativa e organização acadêmica. Brasil, 2002 a 2007

\begin{tabular}{|c|c|c|c|c|c|c|c|}
\hline Ano & $\begin{array}{l}\text { Categoria } \\
\text { Administrativa }\end{array}$ & Total & $\begin{array}{l}\text { Univer- } \\
\text { sidades }\end{array}$ & $\begin{array}{c}\text { Centros } \\
\text { Universitários }\end{array}$ & $\begin{array}{c}\text { Faculdades } \\
\text { Integradas }\end{array}$ & $\begin{array}{c}\text { Faculdades, } \\
\text { Escolas e } \\
\text { Institutos }\end{array}$ & ${\mathrm{CET} / \mathrm{FaT}^{1}}^{1}$ \\
\hline \multirow{4}{*}{2002} & Total & 41,4 & 41,8 & 40,5 & 49,1 & 41,2 & 26,5 \\
\hline & Federal & 39,7 & 40,4 & 55,2 & - & 27,4 & 27,1 \\
\hline & Estadual & 43,7 & 43,9 & - & - & 45,5 & 24,7 \\
\hline & Municipal & 41,8 & 41,8 & 36,5 & 49,1 & 41,5 & - \\
\hline \multirow{4}{*}{2003} & Total & 41,9 & 42,3 & 39,4 & 47,0 & 42,2 & 28,5 \\
\hline & Federal & 40,0 & 40,8 & 57,3 & 50,5 & 25,4 & 28,9 \\
\hline & Estadual & 44,2 & 44,2 & - & - & 47,1 & 26,7 \\
\hline & Municipal & 43,1 & 44,3 & 35,5 & 46,3 & 42,3 & - \\
\hline \multirow{4}{*}{2004} & Total & 42,3 & 43,0 & 43,2 & 50,0 & 42,1 & 29,4 \\
\hline & Federal & 40,2 & 41,3 & 54,4 & - & 24,1 & 30,2 \\
\hline & Estadual & 45,1 & 45,5 & - & - & 47,0 & 25,4 \\
\hline & Municipal & 42,6 & 42,1 & 39,6 & 50,0 & 42,2 & - \\
\hline \multirow{4}{*}{2005} & Total & 42,6 & 43,0 & 42,6 & 50,9 & 44,0 & 32,3 \\
\hline & Federal & 40,3 & 41,1 & - & - & 23,8 & 33,0 \\
\hline & Estadual & 45,6 & 45,7 & - & - & 49,6 & 29,2 \\
\hline & Municipal & 43,6 & 42,8 & 42,6 & 50,9 & 43,2 & - \\
\hline \multirow{4}{*}{2006} & Total & 42,7 & 43,1 & 39,8 & 49,3 & 45,3 & 31,5 \\
\hline & Federal & 40,5 & 41,4 & - & - & 24,9 & 32,0 \\
\hline & Estadual & 45,6 & 45,6 & - & - & 51,0 & 28,7 \\
\hline & Municipal & 43,7 & 43,2 & 39,8 & 49,3 & 43,7 & - \\
\hline \multirow{4}{*}{2007} & Total & 43,7 & 44,3 & 40,1 & 47,8 & 47,1 & 32,3 \\
\hline & Federal & 40,8 & 41,8 & - & - & 21,8 & 33,1 \\
\hline & Estadual & 47,6 & 47,7 & - & - & 52,9 & 27,1 \\
\hline & Municipal & 44,7 & 44,0 & 40,1 & 47,8 & 46,0 & - \\
\hline
\end{tabular}

Notas: ${ }^{1}$ Centros Federais de Educação Tecnológica (CET) e Faculdades de Tecnologia (FaT).

Fonte: Microdados do Censo da Educação Superior (INEP). Elaboração própria.

No tocante ao regime de trabalho, $74,3 \%$ das funções docentes eram exercidas em período integral, $17,7 \%$ sob o regime de tempo parcial e $8,0 \%$ sob o regime hora-aula em 2007. Por outro lado, no que se refere ao grau de formação dos indivíduos, 43,2\% das funções docentes eram exercidas por doutores, $29,0 \%$ por profissionais que possuíam não mais que título de especialista e $27,7 \%$ por mestres.

De acordo com a Tabela 5, as mulheres desempenhavam 40,9\% das funções docentes com doutorado em período integral em 2007. Em contrapartida, representavam $47,3 \%$ dos vínculos exercidos por até especialistas, sob o regime horista. 
É de supor que os profissionais inseridos no ensino superior sob o regime de tempo integral de trabalho possuam maiores chances de progressão profissional no interior da IES ao qual estão vinculados que aqueles que dividem sua jornada de trabalho entre duas ou mais instituições. No tocante ao grau de formação, o título de doutor é pré-requisito para o avanço na carreira acadêmica propriamente dita, havendo um grande número de IES públicas que evitam contratar profissionais sem essa titulação.

Assim, o fato de encontrar-se proporção superior de mulheres nas funções docentes até especialização na condição de horistas, em relação à sua representação nas funções com doutorado em período integral, indica uma inserção de pior qualidade no ensino superior, que pode explicar, em alguma medida, sua maior dificuldade de progressão na carreira. Os homens, por outro lado, encontram-se inseridos em situação mais favorável à ascensão na hierarquia acadêmica ou administrativa da instituição, a julgar pelos dados aqui analisados.

Cabe, no entanto, contemporizar apontando que a proporção de mulheres entre as funções docentes de pior qualidade - horistas sem mestrado ou doutorado - apresenta-se estagnada desde 2004, ao passo que a proporção feminina entre as funções com doutorado em período integral vem apresentando tendência ligeiramente ascendente - aumentou dois pontos percentuais em três anos.

Tabela 5

Evolução da proporção de mulheres nas funções docentes em exercício, segundo grau de formação e regime de trabalho. Brasil, 2004 a 2007

\begin{tabular}{|c|c|c|c|c|c|}
\hline Ano & Titulação & Total & $\begin{array}{c}\text { Tempo } \\
\text { Integral }\end{array}$ & $\begin{array}{l}\text { Tempo } \\
\text { Parcial }\end{array}$ & Horista \\
\hline \multirow{4}{*}{2004} & Total & 42,3 & 42,6 & 40,0 & 44,8 \\
\hline & Até Especialização & 44,3 & 43,7 & 44,0 & 47,4 \\
\hline & Mestrado & 46,2 & 48,0 & 40,5 & 41,7 \\
\hline & Doutorado & 37,7 & 38,9 & 26,3 & 36,2 \\
\hline \multirow{4}{*}{2005} & Total & 42,6 & 42,6 & 41,2 & 46,1 \\
\hline & Até Especialização & 44,4 & 43,2 & 45,1 & 47,3 \\
\hline & Mestrado & 46,9 & 48,0 & 42,8 & 45,5 \\
\hline & Doutorado & 38,2 & 39,2 & 26,1 & 40,2 \\
\hline \multirow{4}{*}{2006} & Total & 42,7 & 42,6 & 40,9 & 46,1 \\
\hline & Até Especialização & 44,2 & 42,7 & 44,8 & 47,4 \\
\hline & Mestrado & 46,7 & 47,8 & 42,3 & 45,9 \\
\hline & Doutorado & 38,9 & 39,8 & 28,1 & 39,5 \\
\hline \multirow{4}{*}{2007} & Total & 43,7 & 43,4 & 43,5 & 46,1 \\
\hline & Até Especialização & 45,5 & 43,7 & 47,2 & 47,3 \\
\hline & Mestrado & 47,1 & 48,1 & 43,9 & 44,6 \\
\hline & Doutorado & 40,2 & 40,9 & 31,7 & 43,5 \\
\hline
\end{tabular}

Fonte: Microdados do Censo da Educação Superior (INEP). Elaboração própria. 
Tabela 6

Evolução da proporção de mulheres nas funções docentes em exercício, por grau de formação e categoria administrativa. Brasil, 2001 a 2007

\begin{tabular}{|c|c|c|c|c|c|}
\hline Ano & Titulação & Total & Federal & Estadual & Municipal \\
\hline \multirow{4}{*}{2001} & Total & 41,2 & 39,7 & 43,8 & 38,9 \\
\hline & Até Especialização & 42,6 & 39,7 & 46,6 & 40,2 \\
\hline & Mestrado & 47,5 & 45,9 & 51,4 & 40,4 \\
\hline & Doutorado & 35,1 & 34,9 & 35,6 & 26,8 \\
\hline \multirow{4}{*}{2002} & Total & 41,4 & 39,7 & 43,7 & 41,8 \\
\hline & Até Especialização & 43,0 & 39,2 & 47,7 & 42,5 \\
\hline & Mestrado & 46,7 & 45,3 & 49,6 & 43,3 \\
\hline & Doutorado & 36,1 & 36,2 & 36,2 & 33,1 \\
\hline \multirow{4}{*}{2003} & Total & 41,9 & 40,0 & 44,2 & 43,1 \\
\hline & Até Especialização & 43,5 & 39,6 & 47,7 & 44,3 \\
\hline & Mestrado & 47,0 & 45,3 & 50,7 & 44,3 \\
\hline & Doutorado & 36,9 & 36,9 & 37,1 & 34,4 \\
\hline \multirow{4}{*}{2004} & Total & 42,3 & 40,2 & 45,1 & 42,6 \\
\hline & Até Especialização & 44,3 & 40,3 & 49,5 & 43,5 \\
\hline & Mestrado & 46,2 & 43,9 & 50,0 & 43,5 \\
\hline & Doutorado & 37,7 & 37,8 & 37,7 & 37,2 \\
\hline \multirow{4}{*}{2005} & Total & 42,6 & 40,3 & 45,6 & 43,6 \\
\hline & Até Especialização & 44,4 & 40,2 & 49,8 & 43,6 \\
\hline & Mestrado & 46,9 & 44,3 & 51,1 & 44,8 \\
\hline & Doutorado & 38,2 & 38,1 & 38,2 & 40,7 \\
\hline \multirow{4}{*}{2006} & Total & 42,7 & 40,5 & 45,6 & 43,7 \\
\hline & Até Especialização & 44,2 & 40,0 & 49,0 & 44,8 \\
\hline & Mestrado & 46,7 & 43,7 & 51,6 & 44,1 \\
\hline & Doutorado & 38,9 & 38,9 & 38,9 & 39,3 \\
\hline \multirow{4}{*}{2007} & Total & 43,7 & 40,8 & 47,6 & 44,7 \\
\hline & Até Especialização & 45,5 & 40,1 & 51,6 & 45,4 \\
\hline & Mestrado & 47,1 & 43,4 & 52,5 & 45,5 \\
\hline & Doutorado & 40,2 & 39,8 & 41,0 & 40,6 \\
\hline
\end{tabular}

Fonte: Microdados do Censo da Educação Superior (INEP). Elaboração própria.

Na Tabela 6 verifica-se a evolução, no período 2001-2007, da proporção de mulheres nas funções docentes segundo grau de formação e categoria administrativa. No início da série, havia um hiato importante entre a participação feminina no total de funções docentes $(41,2 \%)$ e sua representação nas funções com doutorado $(35,1 \%)$, sendo a magnitude desse hiato ainda maior nas IES estaduais e municipais.

Ao longo do período, no entanto, esse hiato sofreu redução sistemática nas três categorias administrativas em análise, atingindo, em 2007, os valores de 1,0, 6,5 e 4,1 pontos percentuais nas IES federais, estaduais e municipais, respectivamente. 
Esse comportamento reflete, em certa medida, as metas do Plano Nacional da Educação (lei n. 10.172 de 09/01/2001) de aumentar em pelo menos 5\% ao ano o número de mestres e doutores formados no sistema nacional de pós-graduação e de elevar a qualificação de docentes e pesquisadores. De fato, em todas as categorias administrativas analisadas houve uma redução importante na proporção de vínculos ocupados por não doutores entre 2001 e 2007 (Gráfico 2).

Gráfico 2

Evolução da proporção de não doutores nas funções docentes em exercício, por categoria administrativa. Brasil, 2001 a 2007

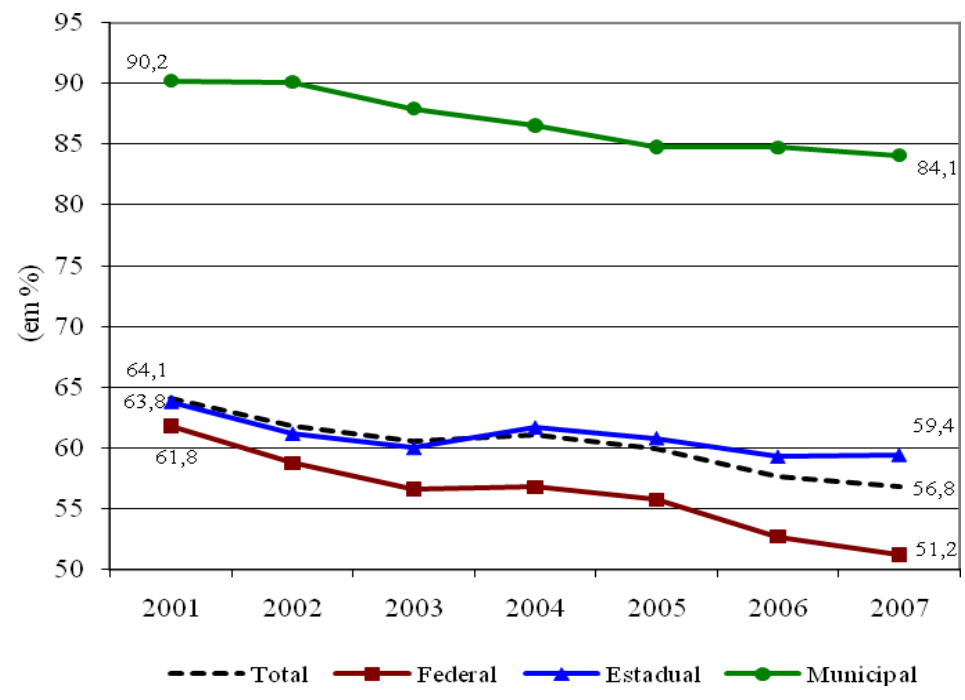

Fonte: Microdados do Censo da Educação Superior (INEP). Elaboração própria.

\section{Faltam às servidoras competências para o exercício de cargos de direção?}

Nesta seção são apresentados e discutidos os resultados de dois estudos recentes que buscam captar a percepção dos dirigentes da administração pública federal acerca da representação feminina nos cargos de comando, investigando as causas por eles atribuídas à disparidade na participação dos dois sexos.

Discutem-se ainda as razões da menor presença de mulheres em posições de prestígio e reconhecimento no meio acadêmico, apresentando-se tanto fatores de ordem social, como institucional.

\subsection{Percepções na administração pública}

A constatação do teto de vidro no setor público brasileiro tem suscitado estudos que buscam conhecer a percepção coletiva dos dirigentes a respeito da representação feminina nos cargos superiores das organizações públicas, identificar 
as competências julgadas necessárias para o exercício dos referidos cargos e investigar se há dimensões de gênero nos atributos apontados.

Seguindo essa linha de investigação, a Escola Nacional de Administração Pública (ENAP, 2006) realizou um estudo quali-quantitativo com ocupantes de cargos DAS 4, 5 e 6 e de natureza especial (ministros, secretários executivos e alguns assessores da Presidência da República) da administração pública federal. Grande parte dos entrevistados do sexo masculino revelou subestimar o grau de desigualdade nas participações de homens e mulheres nos escalões superiores da administração pública. Além disso, o reconhecimento da ocorrência de práticas discriminatórias contra as mulheres foi maior entre os participantes do sexo feminino (85\%) que do masculino (57\%). A discriminação é percebida, por estes indivíduos, principalmente pela menor presença feminina nos escalões superiores apontada por $46 \%$ deles - e pela forma como se fala das mulheres, mencionada por $35 \%$.

A participação feminina nos cargos superiores (DAS 4, 5 e 6) do serviço público federal é considerada insuficiente por $26 \%$ dos respondentes, mais ou menos adequada por outros $26 \%$ e suficiente para apenas $22 \%$. Entre aqueles que a consideram insuficiente ou mais ou menos suficiente, as razões apresentadas para a sub-representação feminina na hierarquia superior são a maior facilidade de acesso dos homens aos quadros superiores, apontada por $69 \%$ dos respondentes, que se associa à herança de uma sociedade patriarcal, mencionada por $64 \%$ deles. Também são citadas a limitação sofrida pelas mulheres em razão da maternidade e dos cuidados com a família $(52 \%)$ e sua menor disposição em disputar cargos de direção $(36 \%)$.

Entre as competências julgadas necessárias para o exercício de funções de direção estão integridade e honestidade, liderança, gestão de equipe, legitimidade, gestão estratégica e negociação, entre outras; $30 \%$ dos respondentes do sexo feminino acham que às mulheres falta alguma dessas características, percentual maior que entre todos os respondentes (20\%). Elas apontam como deficiências femininas, principalmente, a falta de confiança em si mesmas, a falta de gestão estratégica e a menor resistência ao stress e às pressões.

Em outro estudo, Fontenele-Mourão (2006) entrevista sete mulheres ocupantes de postos de gerência do topo da carreira da Administração Pública (cargos DAS 5, 6 e de natureza especial), realizando perguntas a respeito de três temas: poder e relações interpessoais no trabalho, competência gerencial versus competência de gênero e conciliação entre trabalho e vida pessoal. Por meio da

(16) Muitos também citaram a falta de oportunidade de ascensão profissional sofrida pelas mulheres (23\%), a maneira como são tratadas pela chefia (23\%), os salários inferiores (16\%) que recebem e o tratamento que lhes é conferido pelos subordinados quando elas são chefes (15\%). 
análise qualitativa das respostas e de um software que realiza análise estatística textual, a fim de identificar padrões repetitivos de linguagem, a autora reconhece um discurso coletivo comum entre as gerentes.

Elas atribuem a conquista profissional (no caso, o cargo de direção que alcançaram) ao mérito e a uma longa trajetória de dedicação e esforço pessoal, sem favorecimentos. Apesar da comprovada competência profissional, reconhecem que a ascensão na carreira exigiu a superação de preconceitos.

Além da necessidade de se afirmar perante os subordinados, as próprias gerentes revelam-se preocupadas em se superar e comprovar seu desempenho para serem respeitadas e reconhecidas como competentes para as funções de liderança. Para quase todas elas, o desempenho da função gerencial implica maior dedicação e disponibilidade, com uma carga de trabalho maior, horários irregulares e, não raro, a extensão da jornada de trabalho para os finais de semana. Diante disso, o apoio familiar é apontado como condição essencial para a conciliação das vidas profissional e pessoal.

Os relatos pessoais apontam ainda a existência de uma forma feminina de gerenciar, caracterizada pela forte preocupação com o modo de tratar as pessoas, pela ênfase no trabalho em equipe e pela tentativa de amenizar conflitos. Essa forma de gerenciar contrastaria com o estilo masculino, apontado como severo e autoritário.

Na percepção das entrevistadas, a aprendizagem adquirida dentro de casa, na gestão das múltiplas tarefas e dos conflitos familiares, constitui um diferencial feminino que lhes permite lidar melhor com as pessoas no ambiente de trabalho.

Posteriormente, Fontenele-Mourão (2006) investiga como as equipes concebem o gerenciamento feminino. Neste caso, em lugar de entrevistas individuais, elabora-se um roteiro para preenchimento baseado na técnica de livre associação, tendo como termo indutor "trabalhar com uma mulher gerente é...". Os participantes são 146 indivíduos (74 dos quais mulheres) ocupantes de postos de diferentes níveis hierárquicos da Administração Pública, membros das equipes de trabalho lideradas pelas gerentes que foram alvo da primeira parte do estudo. $\mathrm{O}$ procedimento de análise de dados baseia-se em software que analisa a frequência e a ordem de evocação das respostas. Com base nesses dois critérios identificam-se os elementos mais importantes associados ao termo indutor, construindo-se, assim, a percepção coletiva a respeito do gerenciamento feminino.

Entre os elementos considerados mais representativos do gerenciamento feminino, na percepção das equipes chefiadas por mulheres e segundo o critério de análise de dados adotado, estão os que se associam aos termos "organização", "indiferente", "competência", "flexibilidade" e "compreensão". 
O termo "organização" é empregado tanto com uma conotação positiva, como negativa. Neste último caso, é associado ao detalhismo excessivo, que retarda a tomada de decisões e o andamento do trabalho. Já a palavra "indiferente" indica que, para um número elevado de indivíduos, a competência profissional não está relacionada ao fato de o gerenciamento ser exercido por homem ou por mulher. "Flexibilidade" e "compreensão" dizem respeito à preocupação com o outro, saber ouvir, e valorizar a intuição. O predomínio de uma avaliação positiva da atuação da mulher sugere, nas palavras da autora, “que os espaços públicos já não são percebidos como exclusivos dos homens, uma mudança na forma tradicional de conceber a divisão sexual do trabalho".

Na percepção dos entrevistados de ambos os sexos, a mulher possui um estilo próprio de liderança que se diferencia do masculino pelo maior grau de responsabilidade e empenho no trabalho.

Os resultados das pesquisas de ENAP (2006) e Fontenele-Mourão (2006) mostram, assim, que para a maior parte dos dirigentes há discriminação contra as mulheres para a ocupação de cargos de direção do serviço público federal, sendo a baixa representação feminina nestes cargos um indício disso. O preconceito, porém, não é, via de regra, associado à falta de competência das mulheres para o exercício do poder, prevalecendo uma avaliação positiva tanto de seu desempenho nessas funções como de seu estilo de liderança.

As pesquisas revelam ainda que não apenas a discriminação limita a ascensão profissional feminina. Conflitos entre trabalho e vida pessoal e a menor disposição feminina em disputar cargos de direção também se interpõem à progressão na carreira.

A constatação de um menor reconhecimento da ocorrência de práticas discriminatórias entre os dirigentes do sexo masculino sugere que, enquanto estes prevalecerem nos cargos de direção do serviço público, o enfrentamento do teto de vidro poderá ser negligenciado, reproduzindo-se a participação desigual dos sexos nas instâncias hierárquicas.

Nota-se, por fim, que para $20 \%$ dos dirigentes entrevistados por ENAP (2006) faltam às mulheres competências para o exercício de funções de direção. Não é possível, entretanto, identificar se as deficiências femininas são atribuídas a fatores de ordem biológica ou de socialização. Se estas diferenças são percebidas como o resultado de processos distintos de socialização ao longo da infância e da adolescência - como de fato, o são - há a possibilidade de estes dirigentes perceberem a importância da implementação de programas de capacitação feminina para o exercício de funções de comando. No entanto, se são percebidos como o reflexo de características intrínsecas às mulheres, reduz-se o reconhecimento da eficácia de políticas públicas para a superação do teto de vidro. 


\subsection{Percepções na carreira científica e acadêmica}

Tal como no caso da administração pública federal, a menor velocidade de ascensão feminina nas estruturas de poder dos órgãos de ensino e pesquisa brasileiros está associada, em algum grau, a práticas discriminatórias, manifestas ou veladas, que visam excluir as mulheres das posições de poder. As pesquisadoras da Unicamp entrevistadas por Velho e León (1998), por exemplo, foram quase unânimes em apontar barreiras para avançar nos cargos administrativos da universidade, nos quais são tomadas as decisões relativas às várias políticas universitárias.

A progressão mais lenta das mulheres nos níveis da carreira propriamente acadêmica, no entanto, não é, via de regra, associada à discriminação. $\mathrm{O}$ argumento frequentemente utilizado para justificar o teto de vidro nesse meio, baseado em estudos internacionais, é o da menor produtividade feminina, mensurada principalmente em termos de número de publicações em revistas indexadas e de participações em eventos científicos de prestígio.

Antes de tecer considerações a respeito da validade desse argumento, cabe observar que não há evidências estatísticas robustas, no Brasil, que permitam corroborá-lo ou refutá-lo. Os dados atualmente disponibilizados pela Unicamp e pela Universidade de São Paulo (USP) em seus anuários estatísticos, por exemplo, não apresentam as produções científicas das respectivas comunidades acadêmicas desagregadas por sexo. Para obter tal distribuição, seria necessário compilar as informações dos anuários de pesquisa de todas as unidades acadêmicas de tais universidades, identificando o sexo do autor em cada produção mencionada.

A menor produtividade científica das mulheres, quando verificada, é associada a uma ampla gama de fatores: o menor interesse feminino pela carreira, a falta de ambição, a dificuldade em conciliar as atividades profissionais com as pessoais - em razão da distribuição desigual dos encargos domésticos com o cônjuge -, a preferência feminina pela docência em detrimento da pesquisa. Segundo Schienbinger (2001), os homens produzem mais porque estão mais bem situados institucional e hierarquicamente. Ou seja, o melhor desempenho masculino no mundo acadêmico estaria associado ao fato de os homens deterem uma "vantagem cumulativa": pertencendo às instituições mais prestigiadas, têm acesso a maior volume de recursos e a laboratórios mais equipados, o que impulsiona suas publicações.

No entanto, há evidências de que a produtividade científica por si só não explica a representatividade feminina nos distintos níveis da carreira acadêmica.

Velho e León (1998) analisam as produções científicas de quatro institutos da Unicamp, desagregadas por sexo, no ano de 1996. Verificam uma defasagem entre a participação feminina no corpo docente e sua contribuição à produção 
científica nos institutos de Biologia e Filosofia e Ciências Humanas - justamente aqueles em que as mulheres são mais representativas. No entanto, mesmo nos casos em que a produção feminina se equipara (Instituto de Física) ou supera (Instituto de Química) a masculina, as autoras constatam que as docentes não conseguem avançar na carreira na mesma velocidade que seus colegas.

Para Soares (2001), as mulheres enfrentam barreiras institucionais no meio científico. Seja qual for sua produtividade, seu desempenho tende a ser menos reconhecido. Como exemplo, é citado um estudo realizado pelo Conselho de Pesquisa Médica da Suécia, no qual se constata que para obter suporte financeiro, pesquisadoras devem ser em média 2,2 vezes mais produtivas do que seus colegas do sexo masculino. A baixa representação feminina na Academia Brasileira de Ciências e na Academia Nacional de Medicina, constatadas na seção 2.2 deste trabalho, mostra um escasso reconhecimento da contribuição acadêmica das mulheres dentro da comunidade científica brasileira.

Por fim, uma parte da explicação para a menor presença feminina nas altas instâncias das hierarquias acadêmica e administrativa reside no modelo assimétrico de divisão sexual do trabalho, que atribui às mulheres a maior parte das responsabilidades pelo cuidado da família e do lar. A perspectiva de obtenção de maior prestígio e remuneração no trabalho é menos atrativa para elas, pois tem como contrapartida a ampliação da carga de trabalho, em detrimento do tempo em família. $\mathrm{O}$ frágil equilíbrio entre trabalho e vida pessoal tem que ser revisto para possibilitar à mulher o avanço na carreira, representando, para muitas, um dilema. Tende a prevalecer, como desfecho desse dilema, a priorização da vida familiar e da esfera privada do domicílio em detrimento do espaço público e profissional, em razão da introjeção de normas comportamentais associadas à divisão tradicional de papéis sexuais.

Assim, o que muitas vezes é interpretado como "desinteresse" feminino pela carreira, ou ainda falta de ambição, frequentemente resulta da antecipação, por parte das mulheres, de dificuldades para atender simultaneamente às responsabilidades familiares e profissionais ${ }^{17}$.

\section{Considerações finais}

Este artigo procurou mostrar que, apesar de estarem sujeitas a métodos de seleção de pessoal mais objetivos e transparentes, as carreiras do setor público brasileiro não escapam ao fenômeno do teto de vidro.

(17) Isto parece ser particularmente verdade no caso da disputa por cargos de direção, pois a acumulação das atividades de docência e pesquisa com o desempenho de funções administrativas na universidade exige do docente maior disponibilidade de tempo e flexibilidade de horários. 
A segregação de gênero se faz notar, por exemplo, na administração pública federal, onde se observa uma representatividade feminina decrescente à medida que se avança nos níveis hierárquicos dos cargos do grupo DAS. É também verificada nas organizações de ensino e pesquisa estatais, por meio dos estudos de caso que foram objeto da seção 2.2 deste trabalho ${ }^{18}$.

Assim, a forma tradicional de se conceber a divisão sexual do trabalho segregando as mulheres das posições de decisão e prestígio na sociedade - é, em grande medida, replicada no setor público brasileiro.

A menor presença feminina nos cargos de chefia e direção, no entanto, não deve ser associada exclusivamente às práticas discriminatórias, manifestas ou veladas, que visam excluir as mulheres das posições de poder. É preciso também levar em conta o conflito cotidiano vivido por elas para conciliar suas vidas profissional e pessoal, e que tem origem em uma divisão sexual do trabalho que ainda lhes atribui a maior parte das responsabilidades pelo cuidado da família e do lar. E, não menos importante, a introjeção, por parte das próprias mulheres, de normas comportamentais seculares, associadas a essa divisão tradicional de papéis, que as condicionaram a portarem-se de forma não competitiva, priorizando a vida familiar e a esfera privada do domicílio, em detrimento do espaço público e profissional.

As estruturas institucionais vigentes nas organizações públicas, por outro lado, tendem a perpetuar o quadro de exclusão feminina verificado.

$\mathrm{Na}$ administração pública federal, justamente para os altos postos de comando - os cargos em comissão - inexiste a obrigatoriedade de realização de concurso público para contratação de servidores. O acesso a esses cargos ocorre por nomeação, inclusive de indivíduos que não sejam servidores de carreira do Estado. Assim, não há garantias de que a seleção siga critérios técnicos e universais.

O reduzido número de mulheres em cargos de decisão, ademais, dificulta a implementação de políticas e medidas que estimulem uma maior participação feminina nas instâncias superiores da administração pública.

Por fim, no meio acadêmico, um quadro institucional desfavorável às mulheres também é observado. Elas têm menor acesso a posições de prestígio nas universidades, nos comitês científicos e nas academias de ciências do país. Essa "desvantagem cumulativa" dificulta a obtenção de recursos para pesquisa, os quais

(18) Cabe observar que a constatação do teto de vidro no setor público brasileiro poderia ser corroborada por um número bastante superior de casos se as organizações públicas divulgassem regularmente o número de servidores em atividade, desagregados por sexo, segundo os níveis hierárquicos das carreiras, tal como fazem o Ministério do Planejamento, por meio de seu Boletim Estatístico de Pessoal, e a Universidade Estadual de Campinas, mediante seu Anuário Estatístico. 
são fundamentais para um melhor desempenho acadêmico, e limita as possibilidades profissionais das docentes.

\section{Referências bibliográficas}

BELTRÃO, K. I.; ALVES, J. E. D. A reversão do hiato de gênero na educação brasileira no século XX. In: ENCONTRO NACIONAL DE ESTUDOS POPULACIONAIS, 14, Caxambu, Disponível em: <http://www.abep.nepo.unicamp.br/site_eventos_abep/PDF/ ABEP2004_111.pdf>. Acesso em: 20 out. 2008.

; TEIXEIRA, M. P. Cor e gênero na seletividade das carreiras universitárias. In: SOARES, S. et al. (Org.). Os mecanismos de discriminação racial nas escolas brasileiras. Rio de Janeiro: Ipea, 2005. cap. 6, p. 143-193.

BERNARDES, F. C.; MOURA, M. G.; ACCO, M. A C. Diagnóstico da situação da mulher na administração pública federal. Brasília: ENAP, 1998. (Textos para Discussão, n. 28). Disponível em: <http://www.enap.gov.br/index.php?option=content\&task =view\&id=259\&Itemid=70>. Acesso em: 24 jul. 2008.

BRISOLLA, S. N.; VASCONCELlOS, E. C. C.; PIMENTEL, R. A presença feminina no estudo e no trabalho da ciência na Unicamp. Jornal da Unicamp, Campinas, 20-26 ago. 2007. Opinião, p. 2. Disponível em: <http://www.unicamp.br/unicamp/unicamp_hoje/ju/ agosto2007/ju368pag02.html >. Acesso em: 2 abr. 2009.

DGAFP. Fonction publique: chiffres-clés 2008. Ministère du budget, des comptes publics et de la fonction publique/DGAFP, sept. 2008. 16p. Disponível em: <http://www.fonctionpublique.gouv.fr/IMG/Chiffres_cles_2008.pdf. Acesso em: 19 maio 2009.

ENAP. Gênero, raça e competências de direção no Serviço Público Federal. Brasília: Escola Nacional de Administração Pública (ENAP), 2006. 68p. (Cadernos ENAP, n. 31). Disponível em: <http://www.enap.gov.br/index.php?option=com_docman\&task=doc download\&gid=2210>. Acesso em: 7 abr. 2009.

ETHOS. Perfil social, racial e de gênero das 500 maiores empresas do Brasil e suas ações afirmativas - Pesquisa 2007. São Paulo: Instituto Ethos, 2007. Disponível em: <http://www.uniethos.org.br/_Uniethos/Documents/PesquisaDiversidade2007.pdf>. Acesso em: 17 dez. 2007.

FONTENELE-MOURÃO, T. M. Mulheres no topo de carreira: flexibilidade e persistência. Brasília: Secretaria Especial de Políticas para as Mulheres, 2006. 92p. Disponível em: 〈http://200.130.7.5/spmu/docs/topo_carreira_fim.pdf>. Acesso em: 17 mar. 2009.

GEORGES, I. Entre vida doméstica e vida profissional: engenheiras no Brasil e na França. In: Costa, A. O. et al. (Org.). Mercado de trabalho e gênero: comparações internacionais. Rio de Janeiro: Editora FGV, 2008. cap. 13, p. 245-261. 
HIRATA, H.; KERGOAT, D. Divisão sexual do trabalho profissional e doméstico: Brasil, França, Japão. In: Costa, A. O. et al. (Org.). Mercado de trabalho e gênero: comparações internacionais. Rio de Janeiro: Editora FGV, 2008. cap. 14, p. 263-278.

INEP. Resumo técnico: Censo da Educação Superior 2007. Brasília: Instituto Nacional de Estudos e Pesquisas Educacionais Anísio Teixeira (INEP/MEC), 2009. 47p. Disponível em: 〈http://www.inep.gov.br/download/superior/censo/2007/Resumo_tecnico_2007.pdf>. Acesso em: 10 ago. 2009.

LETA, J.; CARISEY, M.; SÉCHET, P.; OHAYON, P. As mulheres na pesquisa, no desenvolvimento tecnológico e na inovação: Uma comparação Brasil/França. Revista do Serviço Público, Brasília, ENAP, ano 57, n. 4, p. 531-548, out./dez. 2006.

LOMBARDI, M. R. Engenheira e gerente: Desafios enfrentados por mulheres em posições de comando na área tecnológica. In: COSTA, A. O. et al. (Org.). Mercado de trabalho e gênero: comparações internacionais. Rio de Janeiro: Editora FGV, 2008. cap. 21, p. 387402.

MARRY, C. As carreiras das mulheres no mundo acadêmico: O exemplo da biologia. In: COSTA, A. O. et al. (Org.). Mercado de trabalho e gênero: comparações internacionais. Rio de Janeiro: Editora FGV, 2008. cap. 22, p. 401-419.

MELO, H. P.; LASTRES, H. M. M. Ciência e tecnologia numa perspectiva de gênero: o caso do CNPq. (s.d.). Disponível em: 〈http://www.cbpf.br/ mulher/hildete2.pdf >. Acesso em: 03 jun. 2009. O documento realmente não contém data, embora seja provavelmente 2003.

; CASEMIRO, M. C. P. A Ciência no feminino: uma análise da Academia Nacional de Medicina e da Academia Brasileira de Ciência. Revista Rio de Janeiro, Rio de Janeiro, UERJ, n. 11, set./dez. 2003. Disponível em: <http://www.forumrio.uerj.br/ documentos/revista_11/11-Hildete.pdf>. Acesso em: 3 jun. 2009.

SCHIENBINGER, L. O feminismo mudou a ciência? Bauru: Edusc, 2001. 382p. Disponível em: 〈http://brasil.indymedia.org/media/2007/06//386937.pdf〉. Acesso em: 1 jun. 2009.

SCHWEITZER, S. As mulheres e o acesso às profissões superiores: uma comparação européia, séculos XIX e XX. In: Costa, A. O. et al. (Org.). Mercado de trabalho e gênero: comparações internacionais. Rio de Janeiro: Editora FGV, 2008. cap. 20, p. 371-385.

SOARES, T. A. Mulheres em ciência e tecnologia: ascensão limitada. Química Nova, São Paulo: v. 24, n. 2, p. 281-285, mar./abr. 2001. Disponível em: <http://www.scielo.br/pdf/qn/ v24n2/4292.pdf>. Acesso em: 3 jun. 2009.

VELHO, L.; LEÓN, E. A construção social da produção científica por mulheres. Cadernos Pagu, n. 10, p. 309-344, 1998. Disponível em: <http://www.pagu.unicamp.br/files/ cadpagu/Cad10/pagu10.12.pdf >. Acesso em: 31 maio 2009. 